Int. J. Curr. Res. Med. Sci. (2017). 3(6): 41-44

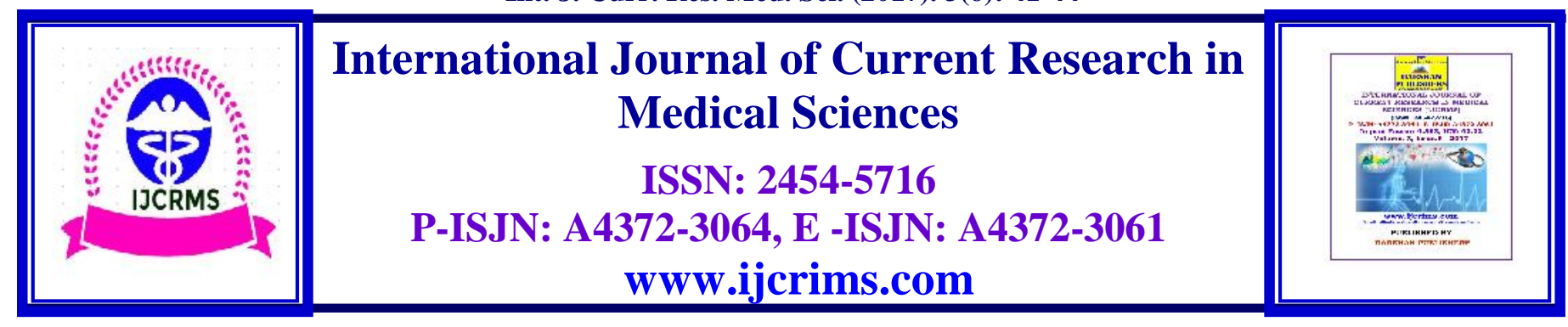

Case Report

Volume 3, Issue 6 -2017

DOI: http://dx.doi.org/10.22192/ijcrms.2017.03.06.006

\title{
CA Cervix metastasising to the abdominal wall - A rare case report
}

\author{
*Vikas Devkare, **Neeraj Bisht, ***Milon Taye, ****N.S.Neki \\ *Assistant Professor, Dept. of Obstetrics and Gynaecology, Govt. Medical College, Miraj, Maharashtra, \\ India ,416410 (Ex Junior Resident, Dept of Obstetrics and Gynaecology, Assam Medical College, \\ Dibrugarh, India, 786002) \\ **Senior Resident, Dept. of Pathology, Govt. Medical College. Amritsar, India, 143001 \\ (Ex, Junior Resident Pathology, Assam Medical College, Dibrugarh, India, 786002) \\ ***Associate Professor, Dept. of Obstetrics and Gynaecology, Assam Medical College, Dibrugarh, \\ India, 786002 \\ *****Professor Medicine, Govt. Medical College, Amritsar, India, 143001 \\ Corresponding Author: Dr. Neeraj Bisht, Senior Resident Pathology, Govt. Medical College, \\ Amritsar, India, 143001 \\ E-mail: drneerajbisht@gmail.com
}

\begin{abstract}
Carcinoma cervix is the leading cause of cancer death among women worldwide. Carcinoma of cervix is second to fourth most common malignancy in women. More than $70 \%$ women report at stage III or higher at diagnosis. Metastasis to the skin occurs rarely in gynaecologic cancer. Ca cervix commonly metastasise to bone, lungs and liver. We report a case of carcinoma cervix stage IB2 treated with radical surgery. Patient was advised postoperative radiotherapy. Two and half months after surgery and receiving radiotherapy, She developed pain and lump in the abdominal wall. Ultrasonography revealed subrectus organized haematoma. Two months later she presented with increase in the size of lump in the abdominal wall. FNAC revealed malignant pathology. Excision of the mass was done. Histopathological examination showed non keratinizing squamous cell carcinoma. Cutaneous metastasis is a rarity with carcinoma cervix and is considered as an ominous prognostic sign.
\end{abstract}

Keywords: Carcinoma Cervix, Metastasis,

\section{Introduction}

Cervical malignancy accounts for $15 \%$ of female malignancies, which metastasizes to the pelvis, lungs, bones, and liver ${ }^{(1)}$. Metastasis to the skin is an unusual presentation during the course of carcinoma of the cervix. The prognosis after skin metastasis is poor and often a terminal presentation. Metastatic carcinomato the skin is an uncommon occurrence, with incidence rate of $5 \%$ or less ${ }^{(2)}$.Imachi et al. suggested that the incidence of skin metastases may vary depending 
on the cell type. Incidence was $0.9 \%$ in patients with squamous cell carcinoma, $5.8 \%$ in adenocarcinoma and $20 \%$ in undifferentiated carcinoma. ${ }^{(3)}$ The prognosis after skin metastasis is poor and often a terminal presentation.

\section{Case Report}

A 28 years old parous female, housewife, from Jorhat (ASSAM), of low socioeconomic strata, attended Gynaecology department on 15 Dec 2009 at Assam Medical College, Dibrugarh. She presented with complains of inter menstrual bleeding for 3 months. On examination cervix showed an exophytic growth, which bled on touch. Patient had undergone total abdominal hysterectomy with bilateral salphingooophorectomy on 23 December 2009 under GA. On FIGO staging it was stage IB2.Histopathological report confirmed nonkeratinising squamous cell carcinoma. Radiotherapy was advised to the patient. After two and half months patient developed pain and lump in the abdominal wall. USG revealed subrectus organized haematoma. Again two months later, she presented with increase in the size of lump in the abdominal wall. On examination an extensive tender swollen mass of size $5.5 \times 5.0 \mathrm{~cm}$ deep beneath the lower abdominal wall, was seen in the scar line below the umbilicus.(see Fig 1)

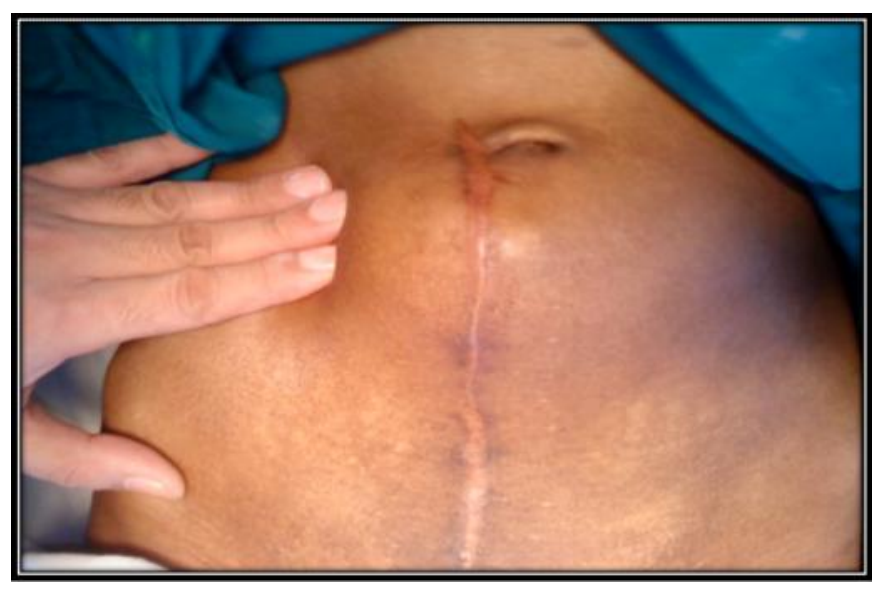

FIG 1.Mass in the abdominal wall.

USG revealed a solid echogenic mass of $6.0 \times 6.5$ x $5.0 \mathrm{~cm}$. Chest X-RAY was normal.

FNAC of the growth was positive for malignant cells consistent with previous histology of squamous cell carcinoma.

Laparotomy done on 23th June, 2010 under spinal anaesthesia detected solitary mass in abdominal wall mass was above the peritoneum \& below the rectus muscle. Excision of the mass was done in piecemeal \& sent for HPE. Peritoneum was opened. No adhesions to omentum or bowels were found. Vaginal vault was normal. There was no secondaries in the pelvis. Lymph nodes were not enlarged. (see Fig 2) 
Int. J. Curr. Res. Med. Sci. (2017). 3(6): 41-44

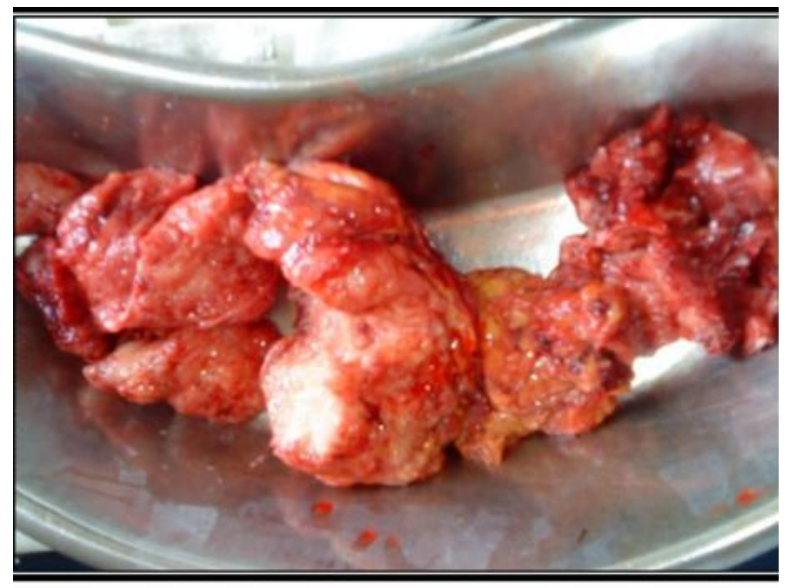

FIG.2.excsied solitary mass.

Histopathological examination confirmed nonkeratinising squamous cell carcinoma (see Fig

3)

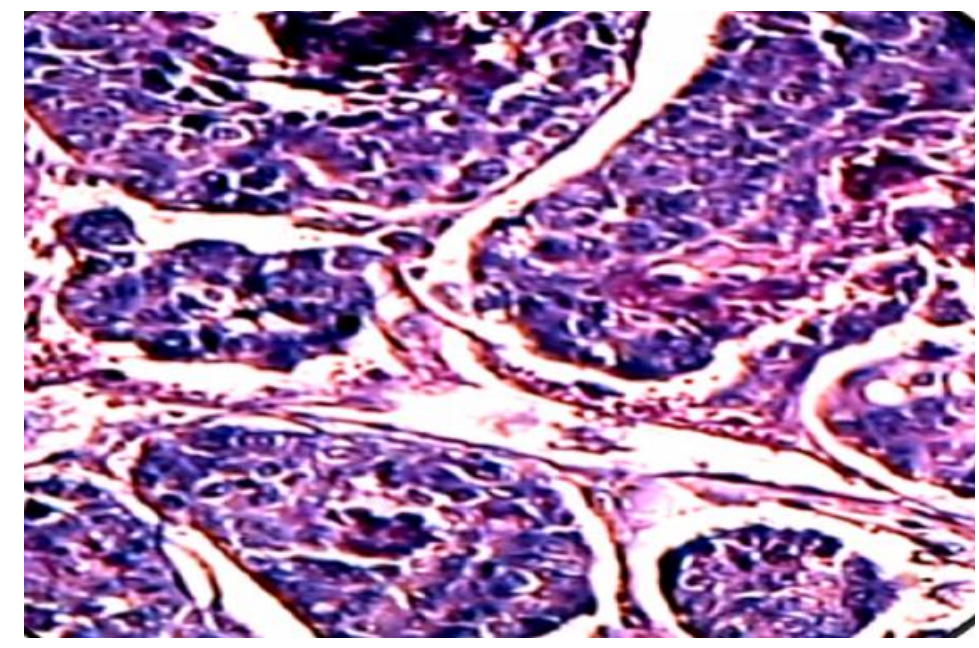

FIG3 HPE: Non Keratinising squammous cell carcinoma.

\section{Discussion}

Skin metastasis from carcinoma cervixis is an unusual entity. To the best of our knowledge, only 25 such cases have been reported in the medical literature. The histological types that most commonly give rise to cutaneous metastasis are adenocarcinoma and undifferentiated carcinoma, whereas squamous cell carcinoma rarely does. ${ }^{(4)}$ The frequent sites of cutaneous metastasis in decreasing order are abdominal wall, vulva and anterior chest wall ${ }^{(4)}$.Skin metastasis has been reported to develop upto $10 \mathrm{yrs}$ after initial diagnosis with an average being less than one year. Deshmukh $U$ et al reported a case of isolated port site recurrence 4 years following laparoscopic surgery in a patient with nodenegative, clinical stage IB1 cervical adenocarcinoma. This study concluded that these patients should be closely monitored for recurrent disease with continued vigilance and long-term follow-up, including persistent attention to and thorough examination of port-sites at each outpatient visit. ${ }^{(5)}$ The case reported here is a very rare, as the abdominal wall metastasis specially in between the rectus muscle and peritoneum developed after treatment, with no evidence of associated loco-regional or distant metastasis at any other site. Ramirez et al. showed that in a median follow-up period of 12 months, $63 \%$ of patients died of disease ${ }^{(6)}$. 
Int. J. Curr. Res. Med. Sci. (2017). 3(6): 41-44

\section{Conclusion}

Metastasis to the skin occurs rarely in gynaecologic cancer. Cacervix Commonly metastasise to bone, lungs and liver. Based on the common metastasis of adenocarcinomas, one could understand the possible mechanism of cervical adenocarcinomas; however, it is difficult to clarify the mechanism in squamous cell carcinomas. Cutaneous metastasis is a rarity with carcinoma cervix and is considered as an ominous prognostic sign.

\section{Source of funding: Nil}

\section{Conflict of interest: None declared}

\section{References}

1. Hema Sinhasane and Sarvottam B. Rao Abdominal Incision Metastasis from Carcinoma Cervix After Wertheim's Hysterectomy. J Obstet Gynaecol India. 2012 Dec; 62(Suppl 1): 89-90.
2. Verma S, Kaur T, Verma R, Dhawan S. Scar Site Metastasis in Cervical Carcinoma. A Case Report and Review of Literature..JK Science. Jan-Mar2013, Vol. 15 Issue 1, p4144. $4 \mathrm{p}$.

3. Imachi M, Tsukamoto N, Kinoshita S, Nakano H. Skin metastasis from carcinoma of the uterine cervix. Gynecol Oncol. 1993;48(3):349-54.

4. Elamurugan TP, AgrawalA, Dinesh R, Aravind R, Naskar D, Kate et al.Palmar cutaneous metastasis from carcinoma cervix. 2011 (77) 2252.

5. Deshmukh U, McAdow M, Black J, Hui P,B , Azodia M. Isolated port site recurrence of node-negative clinical stage IB1 cervical adenocarcinoma. Gynecol Oncol Rep. 2017 May; 20: 54-57

6. Ramirez PR, Frumovitz M, Wolf JK, Levenback C. "Laparoscopic port-site metastases in patients with gynecological malignancies," Int J Gynecological Cancer 2004;14(6):1070-77.

\begin{tabular}{|c|l|}
\hline \multicolumn{2}{|c|}{ Access this Article in Online } \\
\hline & Website: \\
\hline & www.ijcrims.com \\
\hline Quick Response Code & Subject: \\
\hline
\end{tabular}

How to cite this article:

Vikas Devkare, Neeraj Bisht, Milon Taye, N.S.Neki. (2017). CA Cervix metastasising to the abdominal wall - A rare case report. Int. J. Curr. Res. Med. Sci. 3(6): 41-44.

DOI: http://dx.doi.org/10.22192/ijcrms.2017.03.06.006 